\title{
Appraisal of Climatic Conditions for Potential Solar Energy Applications in Nawabshah and Quetta Cities
}

\author{
Abdul Qayoom Jakhrani \\ Department of Chemical Engineering, \\ Quaid-e-Awam University of \\ Engineering, Science and Technology, \\ Nawabshah, Pakistan \\ aqunimas@hotmail.com
}

\author{
Abdul Rehman Jatoi \\ Department of Energy and Environment \\ Engineering, Quaid-e-Awam University \\ of Engineering, Science and Technology, \\ Nawabshah, Pakistan \\ arjatoi@quest.edu.pk
}

\author{
Muhammad Moosa Jakhrani \\ Department of Electrical Engineering, \\ Indus University, \\ Karachi, Pakistan \\ moosajakhrani@gmail.com
}

\author{
Abdul Nasir Laghari \\ Department of Energy and Environment Engineering, \\ Quaid-e-Awam University of Engineering, Science and \\ Technology, Nawabshah, Pakistan \\ mashaalnasirlaghari@gmail.com
}

\author{
Shakeel Ahmed Kamboh \\ Department of Mathematics and Statistics, Quaid-e-Awam \\ University of Engineering, Science and Technology, \\ Nawabshah, Pakistan \\ shakeel.maths@yahoo.com
}

\begin{abstract}
This study was conducted to appraise climatic conditions for potential applications of solar energy units in Nawabshah and Quetta cities. For that, twenty two annual monthly average data of insolation on horizontal surface, at various slopes on titled surface, air temperature, earth skin temperature was acquired and evaluated through the Statistical Package for the Social Sciences software. It is discovered from the study that Quetta is a more promising place for installation of solar energy applications as compared to Nawabshah as it receives more solar radiations and less air temperature.
\end{abstract}

Keywords-air temperature; insolation; solar systems; climatic conditions

\section{INTRODUCTION}

Climate change influences severely the weather patterns of various countries by reducing precipitation or increasing temperatures [1]. A rise of $0.6^{\circ} \mathrm{C}-1.0^{\circ} \mathrm{C}$ in average temperature in coastal areas of Pakistan has been reported since early 1900s [2]. It is important to mention that Pakistan experienced a rise in temperature of around $0.47^{\circ} \mathrm{C}$ during $1960-2010$ [1]. Power sector is more susceptible to extreme weather conditions, predominantly electricity supply and demand [3]. Currently, Pakistan is confronting stern energy crisis and power failures [4]. The level of electricity dearth has jumped up to about $5000 \mathrm{MW}$, which is being compensated by increasing load shedding from 8 to 14 hours per day. Industrial development has also been slowed down having a negative impact on the economy of the country [3]. Also, the provision of energy amenities needs to be extended to distant areas. Alternative methods of providing energy at home could be arranged to supply uninterrupted power to these areas [4, 5]. This goal can be achieved by utilizing solar energy. Solar energy is wholly dependent on climate conditions of the area and there are many climatic zones in Pakistan [4, 6, 7]. The variety of climatic zones has profound effect on the availability of solar energy. Climatic divisions of Pakistan include highland, lowland, coastal and arid climates. Even the division of climatic zones does not indicate accurately the same conditions throughout the zone as there are variants in rainfall, temperature, humidity etc. in similar climatic zones [8,9].

Nawabshah city is located almost at the geographical center of Sindh province. The climate of Nawabshah is hot to exceptionally hot during summer and cold and foggy during winter [10]. The highest temperatures in the city are typically climbing above $50^{\circ} \mathrm{C}$ from May to August. On May 26, 2010, the air temperature reached up to $52^{\circ} \mathrm{C}$, which was the highest temperature ever recorded in Nawabshah. On January 7, 2011, the temperature in the city dropped to $4^{\circ} \mathrm{C}$. Quetta city is the capital of Balochistan province bordering along Afghanistan [11]. The climate of Quetta is dry and arid, and temperature variants significantly between winter and summer. It is hot in summers and mild to extreme cold in winter [12]. The highest observed temperature is around $42^{\circ} \mathrm{C}$ and the lowest $-18.3^{\circ} \mathrm{C}$ [1]. To analyze the link between electricity consumption and climatic variables requires appropriateness of climate for any particular application. This work is an attempt to compare the weather variability on solar energy applications of Nawabshah and Quetta cities.

\section{MATERIALS AND METHODS}

Comparison of Nawabshah $\left(26.3^{\circ} \mathrm{N}\right.$ and $\left.68.4^{\circ} \mathrm{E}\right)$, Sindh and Quetta $\left(30.1^{\circ} \mathrm{N}\right.$ and $\left.67.0^{\circ} \mathrm{E}\right)$, Balochistan weather parameters was made to realize their influence on solar energy application $[10,12,13]$. The meteorological data of both locations were acquired from [14]. The methodology adopted for the data comparison is given in Table I. The appraisal was made with the help of SPSS software. 
TABLE I. SATELLITE DATA ACQUISITION $[10,15]$

\begin{tabular}{|c|c|}
\hline Effect & Range \\
\hline Type of database & NASA SSE 6 \\
\hline Level & Global \\
\hline Data inputs & $\begin{array}{c}\text { GEWEX/SRB, 3 + ISCCP Satellite, } \\
\text { Clouds + NCAR, Reanalysis }\end{array}$ \\
\hline Length of data & 1983-2005 \\
\hline Time resolution & 3-h \\
\hline Spatial resolution & 1 arc-degree x 1 arc-degree \\
\hline Insolation & Satellite model \\
\hline Diffuse part of radiation & Diffuse Radiation Model \\
\hline Tilted surface (diffuse model) & RetScreen Model \\
\hline
\end{tabular}

\section{RESULTS AND DISCUSSIONS}

Annual monthly average insolation on horizontal and tilted surfaces is shown in Figure 1. Monthly average yearly insolation on horizontal surface was found to be $5.24 \mathrm{kWh} / \mathrm{m}^{2} / \mathrm{d}$ in Nawabshah [16] and $5.57 \mathrm{kWh} / \mathrm{m}^{2} / \mathrm{d}$ in Quetta. Maximum value of insolation was recorded in May with $6.42 \mathrm{kWh} / \mathrm{m}^{2} / \mathrm{d}$ in Nawabshah and minimum in December with $3.75 \mathrm{kWh} / \mathrm{m}^{2} / \mathrm{d}$, whereas, in Quetta, maximum insolation was recorded in June with $7.6 \mathrm{kWh} / \mathrm{m}^{2} / \mathrm{d}$ and minimum in December with $3.3 \mathrm{kWh} / \mathrm{m}^{2} / \mathrm{d}$. Similarly, monthly average minimum insolation on tilted surface was recorded as $4.68 \mathrm{kWh} / \mathrm{m}^{2} / \mathrm{d}$ in Nawabshah and $4.97 \mathrm{kWh} / \mathrm{m}^{2} / \mathrm{d}$ in Quetta. Maximum value of insolation in Nawabshah was recorded in May with $5.97 \mathrm{kWh} / \mathrm{m}^{2} / \mathrm{d}$ and minimum in December with $3.34 \mathrm{kWh} / \mathrm{m}^{2} / \mathrm{d}$, while, maximum insolation in Quetta was recorded in June with $6.82 \mathrm{kWh} / \mathrm{m}^{2} / \mathrm{d}$ and minimum in December with $2.66 \mathrm{kWh} / \mathrm{m}^{2} / \mathrm{d}$. It is found that both monthly average and minimum insolation values on a horizontal and tilted surface were 6\% more in Quetta than in Nawabshah.

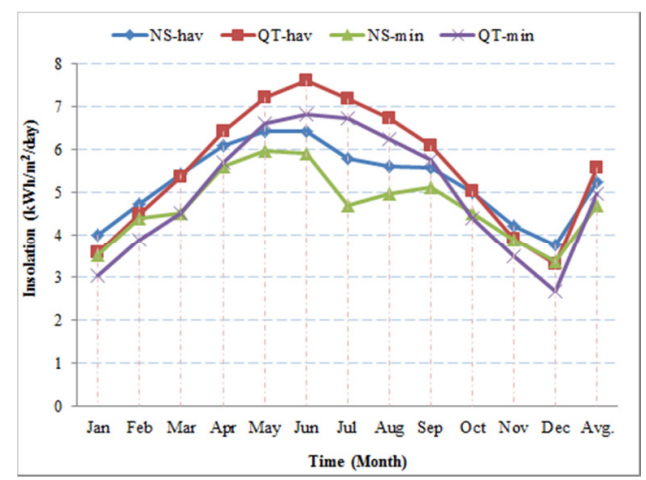

Fig. 1 Monthly average insolation on a horizontal surface and minimum on tilted surface.

The average monthly insolation on tilted surface at different slopes for Nawabshah and for Quetta is shown in Figures 2 and 3 respectively. At slope $\pm 15^{\circ}$ of the latitude of the location, the insolation was in between maximum and minimum values. The average monthly radiation incident on an equator-pointed tilted surface at optimum slopes for both locations is given in Figure 4. It is concluded that Quetta receives approximately 9\% more annual monthly average solar radiations than Nawabshah at optimum slope. In order to consider only worst and best situations at optimum slopes for both locations, monthly minimum average and maximum average radiations were considered and are illustrated in Figure 5. It was found that Quetta receives 7\% more minimum radiation and 10\% more maximum radiation than Nawabshah.

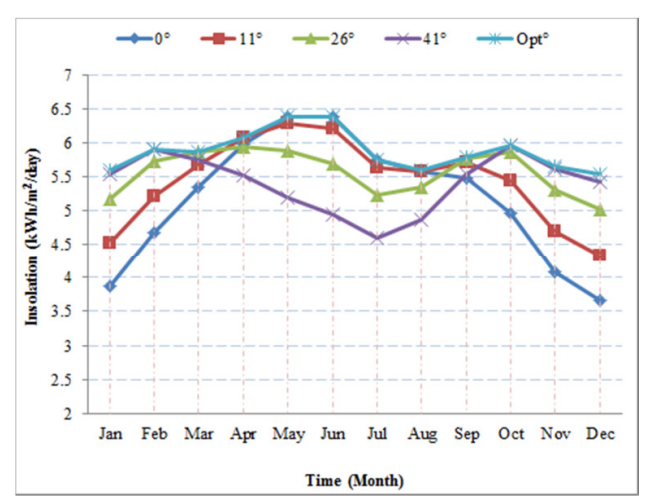

Fig. 2 Monthly average insolation on tilted surface at different slopes at Nawabshah.

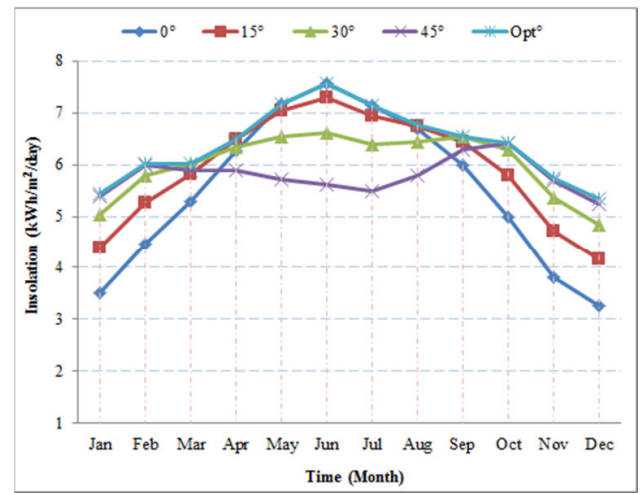

Fig. 3 Monthly average insolation on tilted surface at different slopes at Quetta.

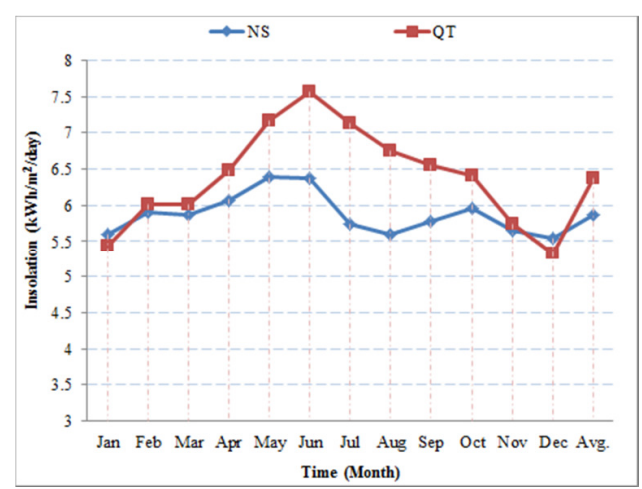

Fig. 4 Monthly average insolation on an equator-pointed tilted surface at optimum slope.

Monthly average yearly mean insolation on all slopes for both locations is illustrated in Figure 6. It was found that both locations receive minimum amount of insolation at $0^{\circ}$ slope and maximum at optimum slope. It was found that Quetta receives $6 \%$ more minimum radiation at $0^{\circ}$, and $9 \%$ more maximum radiation at optimum slope than Nawabshah. It has 
been found that both locations could get maximum insolation at optimum slope. Monthly average and yearly optimum slopes of both locations are depicted in Figure 7.

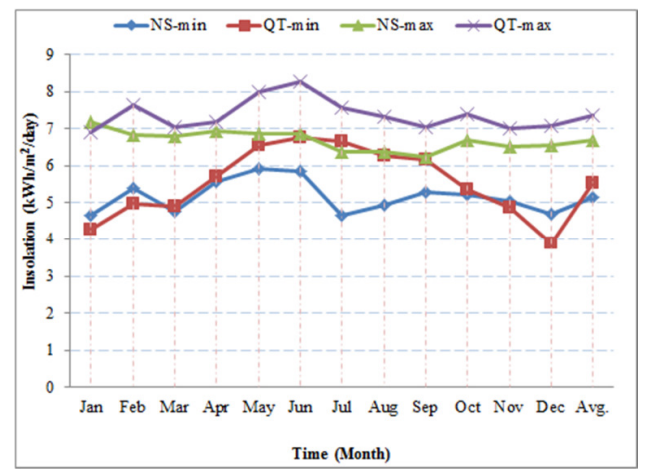

Fig. 5

Monthly averaged minimum and maximum insolation on tilted surface.

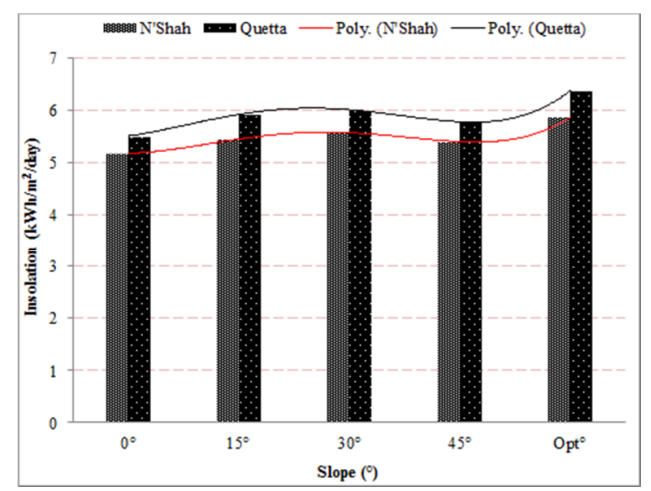

Fig. 6 Monthly average yearly insolation on tilted surface.

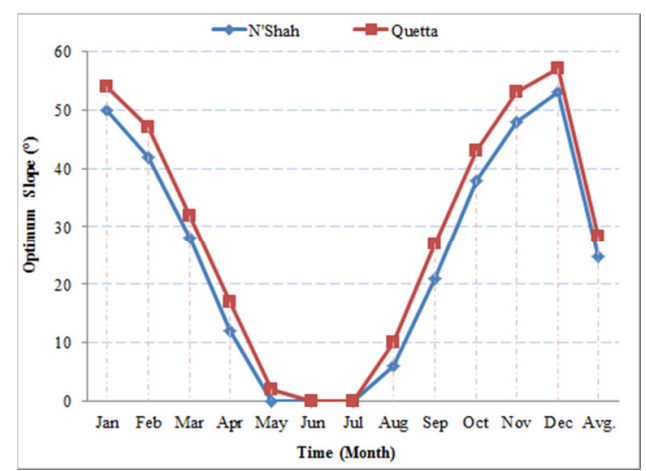

Fig. 7 Monthly average optimum slope for solar system mountings.

It was found that optimum slopes of both locations are almost $2^{\circ}$ less than that of their latitude. For example, Nawabshah is located on $26.24^{\circ} \mathrm{N}$ latitude and its optimum average slope for solar system installations is $24.7^{\circ}$, while Quetta is located on $30.25^{\circ} \mathrm{N}$ and its optimum slope is $38.3^{\circ}$. However, maximum slope of $53^{\circ}$ was determined for Nawabshah in December, and $57^{\circ}$ for Quetta in December. Similarly, $0^{\circ}$ was required for Nawabshah from May to July, whereas, $0^{\circ}$ slope from June to July is best for Quetta.
Temperature is also an important parameter, after solar radiation, for the installation of solar systems, as it has negative relationship with the power output or efficiency of solar photovoltaic systems. Therefore, monthly minimum and maximum average temperature of both locations are illustrated in Figure 8 . Monthly average minimum yearly mean was found $20.7^{\circ} \mathrm{C}$ for Nawabshah and $12^{\circ} \mathrm{C}$ for Quetta, whereas, monthly average maximum yearly mean was $32.6^{\circ} \mathrm{C}$ for Nawabshah and $23.9^{\circ} \mathrm{C}$ for Quetta. Monthly average air and earth skin temperature of both locations are illustrated in Figure 9. Monthly average mean air temperature was found $26.3^{\circ} \mathrm{C}$ for Nawabshah and $18.0^{\circ} \mathrm{C}$ for Quetta, whereas, monthly average mean earth skin temperature was $29.7^{\circ} \mathrm{C}$ for Nawabshah and $21.5^{\circ} \mathrm{C}$ for Quetta. It was found that Quetta has $46 \%$ less average temperature and $38 \%$ less earth skin temperature than Nawabshah. It is concluded from the study that Quetta is a more favorable place for the installation of solar systems as it receives more solar radiation and has less air temperature.

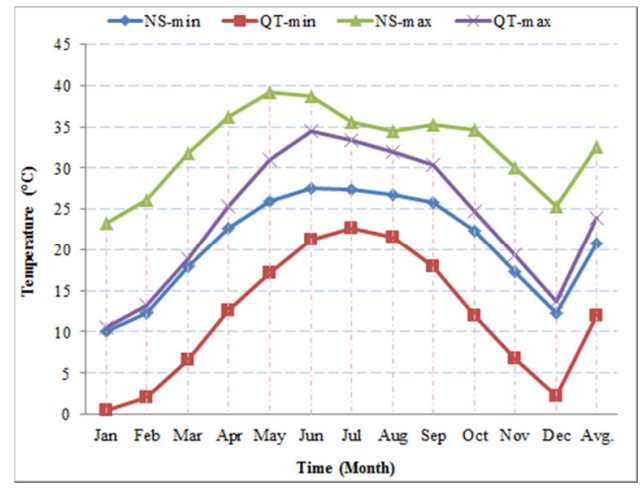

Fig. 8 Monthly average minimum and maximum air temperature.

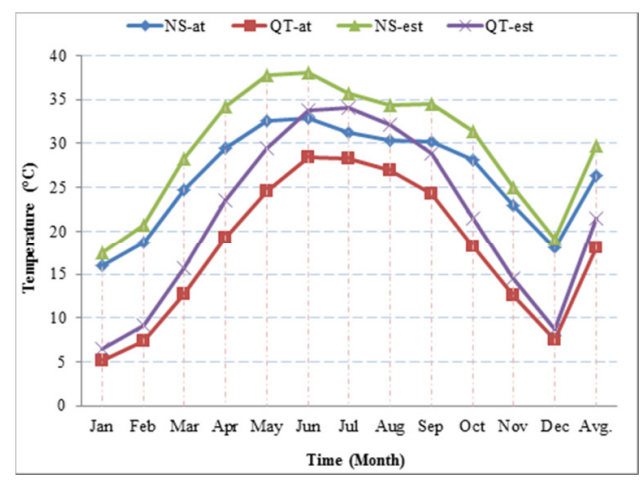

Fig. 9 Monthly average air and earth skin temperature.

\section{CONCLUSIONS}

Monthly average insolation on horizontal surface was found to be $5.24 \mathrm{kWh} / \mathrm{m}^{2} / \mathrm{d}$ in Nawabshah and $5.57 \mathrm{kWh} / \mathrm{m}^{2} / \mathrm{d}$ in Quetta. Monthly average insolation was found maximum at the optimum slope for both locations with $5.87 \mathrm{kWh} / \mathrm{m}^{2} / \mathrm{d}$ for Nawabshah and $6.38 \mathrm{kWh} / \mathrm{m}^{2} / \mathrm{d}$ for Quetta, whereas, minimum insolation was $5.18 \mathrm{kWh} / \mathrm{m}^{2} / \mathrm{d}$ and $5.51 \mathrm{kWh} / \mathrm{m}^{2} / \mathrm{d}$ for Nawabshah and Quetta respectively at $0^{\circ}$ slope. It was found that the optimum slopes of both locations are almost $2^{\circ}$ less 
than their respective latitudes. However, maximum slope of $53^{\circ}$ was determined for Nawabshah and $57^{\circ}$ for Quetta. Similarly, a minimum slope of $0^{\circ}$ was required for both cities. The hottest month at Nawabshah was observed to be May and the coldest was January, whereas, the hottest month at Quetta was June and the coldest was January. It is found that Quetta receives $6 \%$ more insolation on horizontal surface, and $9 \%$ more insolation at optimum slope than Nawabshah. Quetta also gets $6 \%$ more minimum radiation at $0^{\circ}$, and $9 \%$ more maximum radiation at the optimum slope than Nawabshah. Moreover, Quetta has 72\% less minimum temperature and 36\% less maximum temperature than Nawabshah. Quetta also has $46 \%$ less average temperature and $38 \%$ less earth skin temperature than Nawabshah. It is thus concluded that Quetta is a more promising place for the installation of solar systems as it receives more solar radiations and less air temperature.

\section{REFERENCES}

[1] I. H. Durrani, S. Adnan, M. Ahmad, S. M. Khair, E. Kakar, "Observed long-term climatic variability and its impacts on the ground water level of Quetta alluvial", Iranian Journal of Science and Technology, Transactions A: Science, Vol. 42, No. 2, pp. 589-600, 2018

[2] M. J. Iqbal, J. Quamar, "Measuring temperature variability of five major cities of Pakistan”, Arabian Journal of Geosciences, Vol. 4, No. 3-4, pp. 595-606, 2011

[3] M. Ali, M. J. Iqbal, M. Sharif, "Relationship between extreme temperature and electricity demand in Pakistan", International Journal of Energy and Environmental Engineering, Vol. 4, No. 1, pp. 1-7, 2013

[4] P. H. Shaikh, F. Shaikh, M. Mirani, "Solar energy: Topographical asset for Pakistan", Applied Solar Energy, Vol. 49, No. 1, pp. 49-53, 2013

[5] A. Q. Jakhrani, A. K. Othman, A. R. H. Rigit, S. R. Samo, "Comparison of solar photovoltaic module temperature models", World Applied Sciences Journal, Vol. 14, pp. 1-8, 2011

[6] A. Q. Jakhrani, A. K. Othman, A. R. H. Rigit, S. R. Samo, "Assessment of solar and wind energy resources at five typical locations in Sarawak", Journal of Energy and Environment, Vol. 4, No. 1, pp. 1-6, 2013

[7] A. Q. Jakhrani, S. R. Samo, A. R. H. Rigit, S. A. Kamboh, "Selection of models for calculation of incident solar radiation on tilted surfaces", World Applied Sciences Journal, Vol. 22, No. 9, pp. 1334-1343, 2013

[8] S. Bhakta, V. Mukherjee, B. Shaw, "Techno-economic analysis of standalone photovoltaic/wind hybrid system for application in isolated hamlets of North-East India", Journal of Renewable and Sustainable Energy, Vol. 7, No. 2, pp. 1-15, 2015

[9] K. N. Shukla, S. Rangnekar, K. Sudhakar, "Comparative study of isotropic and anisotropic sky models to estimate solar radiation incident on tilted surface: A case study for Bhopal, India”, Energy Reports, Vol. 1, pp. 96-103, 2015

[10] A. Q. Jakhrani, A. R. H. Rigit, M. M. Jakhrani, S. A. Channa, "Comparative analysis of weather parameters at two locations for viability of solar energy systems", Quaid-e-Awam University Research Journal of Engineering, Science \& Technology, Vol. 14, No. 2, pp. 6468,2015

[11] A. S. Khan, S. D. Khan, D. M. Kakar, "Land subsidence and declining water resources in Quetta Valley, Pakistan", Environmental Earth Sciences, Vol. 70, No. 6, pp. 2719-2727, 2013

[12] UNICEF, District Development Profile Quetta, Planning \& Development Department, Government of Balochistan in Collaboration with UNICEF, 2011

[13] M. Ismail, A. Alam, A. R. Masud, M. Hussain, H. Rasheed, "Optimal configuration of hybrid renewable energy system for remote areas of Balochistan", 17th IEEE International Multi Topic Conference, Karachi, Pakistan, December 9-10, 2014

[14] NASA, NASA Surface Meteorology and Solar Energy, available at: https://eosweb.larc.nasa.gov/sse/
[15] A. Angelis-Dimakis, M. Biberacher, J. Dominguez, G. Fiorese, S. Gadocha, E. Gnansounou, M. Robba, "Methods and tools to evaluate the availability of renewable energy sources", Renewable and Sustainable Energy Reviews, Vol. 15, No. 2, pp. 1182-1200, 2011

[16] H. Maammeur, A. Hamidat, L. Loukarfi, M. Missoum, K. Abdeladim, T. Nacer, "Performance investigation of grid-connected PV systems for family farms: case study of North-West of Algeria", Renewable and Sustainable Energy Reviews, Vol. 78, pp. 1208-1220, 2017 